\title{
Maternal periodontitis induces intergenerational injuries on reproductive performance of adult female rat offspring
}

\section{Periodontite materna induz prejuízos transgeracionais no desempenho reprodutivo da prole feminina na idade adulta}

\author{
Suzana Peres PIMENTEL ${ }^{1}$; Marcio Zaffalon CASATI ${ }^{1}$; Fabiano Ribeiro CIRANO ${ }^{1}$; Fernanda Vieira \\ RIBEIRO $^{1}$; Renato Correa CASARIN ${ }^{1}$; Thiago Berti KIRSTEN ${ }^{2}$; Maria Martha BERNARDI ${ }^{2}$ \\ ${ }^{1}$ Universidade Paulista, Programa de Pós-graduação em Odontologia, São Paulo - SP, Brazil \\ ${ }^{2}$ Universidade Paulista, Programa de Pós-graduação em Patologia Ambiental e Experimental, São Paulo - SP, Brazil
}

\begin{abstract}
Substantial evidence suggests a direct link between periodontitis in pregnant women and subsequent adverse pregnancy outcomes. However, no studies have evaluated the transgenerational effects of periodontitis on the reproductive performance of subsequent generations. The present study investigated whether maternal periodontal disease exerts deleterious transgenerational effects on reproductive performance in F1 female rats. Rat female offspring from mothers that were subjected to experimentally induced periodontitis or sham operation were mated with sexually experienced male rats. The weight and reproductive performance of these F1 offspring were evaluated on gestation day 21 , including maternal weight, litter weight, individual pup weight, number of pups, and number of resorptions. The percentage of dams with resorptions and the litter weight/number of pups were also calculated. Compared with the control group, an increase was observed in the percentage and number of resorptions and litter weight/number of pups, and a decrease was observed in the number of pups born in the experimental group. Maternal weight, litter weight, and individual pup weight were not different between the control and experimental groups. Maternal periodontitis impaired reproductive performance in the F1 generation. We showed that periodontitis may induce reproductive injury in adult offspring even if the offspring do not undergo any inflammatory/infectious process during their postnatal life or during gestation. These findings reinforce the importance of oral care during pregnancy.
\end{abstract}

Keywords: Maternal immune activation. Reproduction. Intergenerational effect. Periodontitis. Rat.

\section{Resumo}

Existem evidências substanciais de uma relação direta entre periodontite em mulheres grávidas com efeitos adversos reprodutivos. No entanto, nenhum estudo avaliou os efeitos intergeracionais da periodontite sobre o desempenho reprodutivo das gerações subsequentes. O presente estudo investigou se a doença periodontal materna exerce efeitos intergeracionais deletérios sobre o desempenho reprodutivo em ratos fêmeas da geração F1. Assim, filhas de ratas cujas mães foram submetidas a periodontite experimental ou falsamente operadas foram acasaladas com ratos machos sexualmente experientes. O peso corporal e desempenho reprodutivo da geração $\mathrm{F} 1$ foram avaliados no dia 21 de gestação, incluindo o peso materno, peso da ninhada, peso da individual dos filhotes, número de filhotes e de reabsorções. A percentagem de fêmeas com reabsorção e o peso da ninhada/número de filhotes também foram calculados. Comparados com o grupo controle, observou-se aumento na porcentagem e número de reabsorções e no peso da ninhada/ número de filhotes, e decréscimo no número de filhotes nascidos no grupo experimental. $\mathrm{O}$ peso materno, peso da ninhada e individual dos filhotes não foi diferente entre o controle e experimental. Estes resultados mostram que a periodontite experimental materna prejudica o desempenho reprodutivo da geração $\mathrm{F} 1$, mesmo que estes animais não tenham sido expostos diretamente a um processo inflamatório.

Palavras-chave: Ativação imune maternal. Reprodução. Efeitos intergeracionais. Periodontite. Rato. 
Correspondence to:

Maria Martha Bernardi

Universidade Paulista, Programa de Pós-graduação em

Patologia Ambiental e Experimental

Rua Dr. Bacelar, 1212

CEP 04026-002, São Paulo, SP, Brazil

e-mail: marthabernardi@gmail.com

Received: 09/11/2015

Approved: 03/10/2016

\section{Introduction}

Perinatal lipopolysaccharide (LPS) exposure alters neuroendocrine, immune and behavioral responses in adult rats. The most pronounced effect occurs in female rats compared to males (CAMERON et al., 2008; WALKER et al., 2011; SOMINSKY et al., 2012). In addition, neonatal LPS exposure did not affect the F1 generation fertility but higher mortality and morbidity were observed in litters born to LPS-treated mothers, suggesting that neonatal immunological challenge has a profound impact on the female reproductive development and its possible transferability to a subsequent generation (SOMINSKY et al., 2012).

Periodontal disease is a chronic, low-grade, gramnegative anaerobic infection of periodontal tissues that is associated with an increase in the systemic levels of inflammatory cytokines (PAGE, 1991). Inadequate oral hygiene leads to the accumulation of periodontal bacteria in the gingival crevice of teeth and formation of an organized structure known as "bacterial biofilm." In mature biofilms, the bacteria possess a plethora of virulence factors, including lipopolysaccharide (LPS), which may cause direct destruction of periodontal tissues or stimulate the host to activate a local inflammatory response that, although intended to eliminate the infection, may also lead to the further loss of periodontal structures (BOBETSIS et al., 2006). Moreover, bacteria and/or their shed virulence factors may enter the bloodstream, disseminate throughout the body, and trigger the induction of systemic inflammatory responses and/or ectopic infections (BOBETSIS et al., 2006).
Substantial evidence suggests a direct link between periodontal disease in pregnant women and adverse pregnancy outcomes (PITIPHAT et al., 2008; MICHALOWICZ et al., 2011; PISCOYA et al., 2012; KUNNEN et al., 2014). Periodontal disease affects more than $40 \%$ of pregnant women (LIEFF et al., 2004) and has been linked to adverse pregnancy outcomes, such as preterm delivery (OFFENBACHER et al., 1996; MANNEM; CHAVA, 2011; BOBETSIS et al., 2006; TUCKER, 2006), smaller fetuses (COLLINS et al., 1994; KOTHIWALE et al., 2014), pre-ecclampsia (PATTANASHETTI et al., 2013; MISRATH BANU; RAMAMURTHY, 2014), fetal loss (XIAO et al., 2013), and late miscarriage (MOORE et al., 2005) in the parental generation. However, all of these reproductive impairments have only been studied in the parental generation and not in subsequent generations.

Environmental information that is received by a mother can induce phenotypic changes in her offspring, commonly known as maternal or intergenerational effects (CURNO et al., 2009; WALKER et al., 2011; PENTEADO et al., 2014). Certain cues in the maternal environment (e.g., the prevalence of predators) or maternal infection can lead to behavioral, morphological, and immunological changes in the subsequent generation (WALKER et al., 2011; PENTEADO et al., 2014). To our knowledge, no transgenerational studies have evaluated the effects of maternal periodontal disease on reproductive performance in subsequent generations. Thus, we investigated the reproductive performance of female offspring from rats that were subjected to experimentally induced periodontitis during gestation.

\section{Material and methods}

\section{Animals}

Eighteen female Wistar rats of the parental generation, weighing 180-250 $\mathrm{g}$ and 90-95 days of age, were used at the beginning of the experiments. Nine 
sexually experienced male rats were used for breeding ( 1 male / 2 female). The pregnant female rats were individually housed in polypropylene cages $(38 \times 32 \times$ $16 \mathrm{~cm})$ at a controlled room temperature $\left(22 \pm 2^{\circ} \mathrm{C}\right)$, with artificial lighting $(12 \mathrm{~h} / 12 \mathrm{~h}$ light/dark cycle, lights on at 6.00 AM) and free access to Nuvilab rodent food (Nuvital, São Paulo, Brazil) and filtered water until delivery. Sterilized and residue-free wood shavings were used as animal bedding. The experiments were performed beginning 1 week after their arrival in the laboratory. The animals used in this study were maintained in accordance with the guidelines of the Committee on the Care and Use of Laboratory Animal Resources of Paulista University, São Paulo, Brazil (protocol no. 493/2011 UNIP). These guidelines are similar to those of the National Research Council, USA.

\section{Periodontitis induction}

Female rats of the parental generation underwent general anesthesia through intramuscular administration of ketamine hydrochloride $(10 \mathrm{mg} / \mathrm{kg}$; Dopalen, Agribrands Brasil Ltda., Paulínia, SP, Brazil) and xylazine hydrochloride $(10 \mathrm{mg} / \mathrm{kg}$; Rompun, Bayer S.A., São Paulo, SP, Brazil). They were then randomly assigned to one of the following groups: non-ligature-induced control group $(n=9)$ that only underwent general anesthesia (i.e., sham-operated rats) and ligature-induced experimental group $(n=9)$ that received ligature placement to induce periodontitis as previously reported by our group (PIMENTEL et al., 2013). Under general anesthesia, the upper and lower bilateral first molars of each animal in the ligature-induced experimental group received a cotton ligature (Corrente Algodão, no. 10; Coats Corrente, SP, Brasil) in a cervical position. The thread was introduced in the proximal space between the first and second molars, and the ligatures were kept in position to allow biofilm accumulation. The development of periodontal inflammation in the experimental female rats of the present work was previously described by Györfi et al. (1994). The authors described that, 4 days after ligation, no difference could be observed in vascular permeability in the oral mucosa, but 8 and 14 days after ligation, a significant rise in Evans blue extravasation, one of the characteristic signs of inflammation, occurred. In addition, Kuhr et al. (2004) showed that the ligatureinduced bone loss increased most from day 1 to day 15 ; on days 30 and 60 , slighter increases in bone loss were observed. In our case, because periodontal disease needs the jaws of the females to be removed, we could not follow the development of inflammation, but at weaning the jaws were removed and confirmed the presence of periodontal disease, grade 3 (HUGHES, 2005). Figure 1, of our archives, illustrates the list of the structures prepared to morphometric analysis 11 days after surgical procedures in rats: Aligatures in rats without periodontitis, B- ligatures with periodontal disease.

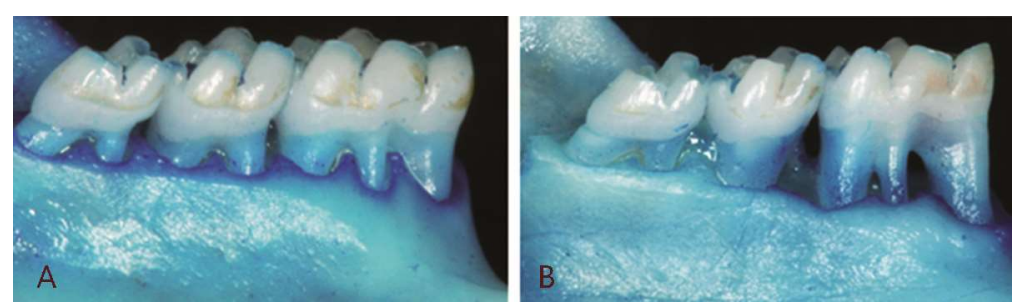

Figure 1 - Images prepared to morphometric studies of the gingiva and teeth of rats 11 days after the ligature procedure. A) teeth with ligature without periodontitis; B) teeth with ligature with periodontitis (grade 4) 


\section{Perinatal procedures}

The peak of periodontitis induced by the present model in rats occurs 10-15 days after the ligature (NASSAR et al., 2003). Because we want to observe the effects of periodontitis on fetal development period (KOCHENOUR, 1984), four days after ligature placement, female rats in estrus (MARCONDES et al., 2002) were mated with sexually experienced male rats (1 male / 2 female) to obtain the F1 generation. Delivery occurred normally, and the offspring (i.e., F1 generation) remained with their mothers until weaning. Litters of less than eight pups were culled. Thus, from the original number of nine pregnant parental rats per group, six pregnant rats of each group were used for the following experiments.

The adult female offspring (F1 generation, postnatal day [PND] 90-95, one female rat from each parental litter) from mothers that presented periodontal disease were evaluated with regard to reproductive performance. For this, adult female F1 rats from dams with periodontitis $(n=6)$ and shamoperated dams $(n=6)$ were mated with other sexually experienced male rats using the same methods as those used for the parental generation. To ensure fertilization, the males remained with the females for 8 days. On gestational day (GD) 21 , the dams of the F1 generation were weighed and anesthetized as described in the parental generation procedures to evaluate reproductive performance, including maternal weight (maternal body weight on GD21 minus litter weight), litter weight, individual pup weight, number of pups, and number of resorptions. The percentage of dams with resorptions and litter weight/number of pups were also calculated.

\section{Statistical analysis}

Homoscedasticity was verified using an $\mathrm{F}$ test or Bartlett's test. Normality was verified using the Kolmogorov-Smirnov test. Student's $t$-test was used to compare weights, the number of pups, litter weight/number of pups, and the number of resorptions. Fisher's exact test was used to compare the percentage data. All of the results were considered significant at $p<0.05$.

\section{Results}

Table 1 shows the reproductive performance of the F1 generation from mothers that were subjected to experimentally induced periodontitis before gestation. Maternal body weight, litter weight, and individual pup weight in the control and experimental groups were not significantly different.

\begin{tabular}{|c|c|c|c|}
\hline Parameter & Control & Experimental & $p$ \\
\hline Maternal body weight $(\mathrm{g})$ & $318.74 \pm 3.85$ & $339.74 \pm 18.26$ & 0.156 \\
\hline Litter weight (g) & $25.86 \pm 1.48$ & $24.36 \pm 2.32$ & 0.292 \\
\hline Individual pup weight (g) & $7.82 \pm 0.08$ & $8.94 \pm 0.07$ & 0.061 \\
\hline
\end{tabular}

Figure 2 shows the number of pups, number and percentage of resorptions, and litter weight/number of pups of the F1 generation from mothers that were subjected to experimentally induced periodontitis. Compared with the control group, (1) the number of pups was lower $(t=2.67, d f=10, p=0.02$; Figure $2 \mathrm{~A})$, 
(2) the number of resorptions was higher $(t=5.29, d f$ $=10, p<0.0004$; Figure 2B), (3) the percentage of resorptions was higher (Figure $2 \mathrm{C}$ ), and (4) the litter weight/number of pups was higher $(t=1.82, d f=10, p$
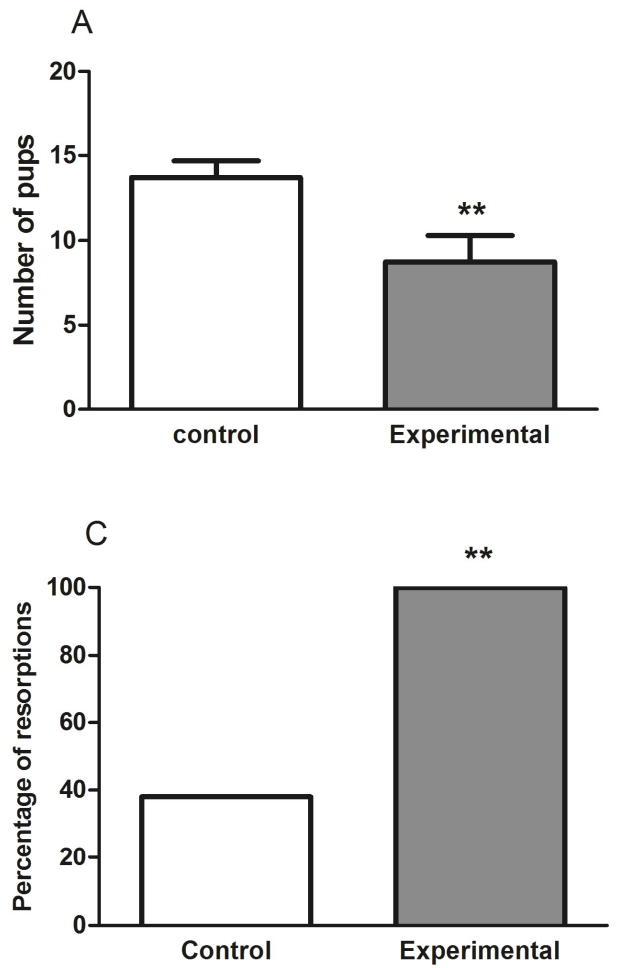

$=0.05$; Figure 2D) in the experimental group. Thus, maternal periodontitis impaired reproductive performance of the F1 generation.
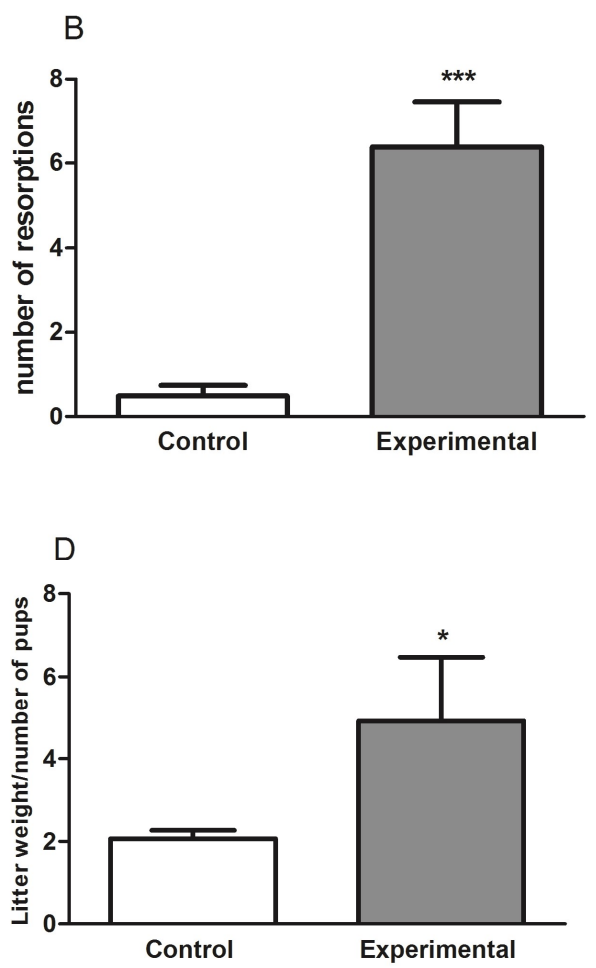

Figure 2 - (A) Number of pups, (B) number and (C) percentage of resorptions, and (D) litter weight/number of pups of the F1 generation from mothers that were subjected to experimentally induced periodontitis before gestation. Control = F1 generation of dams that only underwent anesthesia (i.e., sham-operated rats). Experimental = F1 generation of dams with ligatureinduced periodontitis. The data are expressed as mean \pm SEM or percentages. $n=6 /$ group. ${ }^{*} p<0.05,{ }^{* *} p<0.01,{ }^{* * *} p<0.001$, compared with control group (Student's $t$-test for numbers and weights; Fisher's exact test for percentages)

\section{Discussion}

In our previous investigation of this model of periodontitis, we evaluated the general activity and reproductive performance of the maternal generation that was subjected to experimentally induced periodontitis (PIMENTEL et al., 2013). Social behavior and frontal cortex reelin levels were also investigated in pups of the F1 generation from dams with periodontitis. Interestingly, reproductive performance was unimpaired in the parental generation that had periodontitis during gestation.

Studies with murine models and humans indicate that periodontal diseases may induce adverse pregnancy outcomes (OFFENBACHER et al., 1996; WANG et al., 2013). LPS from Porphyromonas gingivalis increased maternal blood pressure, induced placental and fetal growth restriction, and increased fetal resorptions in rats. $P$. gingivalis was also shown to induce hepatic and uterine translocations in a murine model (LIN et al., 2003). The effects of maternal infection on the developing fetal brain have been suggested to be mediated by cytokine induction within the maternal circulation or placenta (GOLDENBERG et al., 2000). However, these previous studies investigated the parental generation. No studies of which we are aware evaluated the transgenerational 
effects of periodontitis on reproductive performance of subsequent generations.

In the present study, we found that maternal periodontitis during pregnancy induced adverse outcomes in the F1 generation. The F1 generation of the experimental group exhibited a reduction of the number of pups and an increase in the number and percentage of resorptions compared with the control group. This reproductive performance impairment is interesting, especially because the offspring of this F1 generation did not undergo any inflammatory/infectious process during their postnatal development or during gestation of the F2 generation.

However, no differences were observed between groups in maternal weight or litter weight. These results may be explained by the increase in the litter weight/number of pups in the experimental group. When each litter weight was divided by the respective number of pups, this index revealed that the lack of differences between the litter weights was compensated by a reduced number of pups. This reduction of the number of pups born in the experimental group resulted from the increase in the number and percentage of resorptions. Thus, maternal periodontitis reduced the viability of the F1 generation.

The present data suggest a transgenerational effect of maternal inflammation induced by periodontal disease. We demonstrated reproductive injury in the F1 generation while they were pregnant with the F2 generation. A possible mechanism that underlies these

\section{References}

BOBETSIS, Y. A.; BARROS, S. P.; OFFENBACHER, S. Exploring the relationship between periodontal disease and pregnancy complications. Journal of the American Dental Association v. 137, p. S7-S13, 2006. Supplement 2. doi: 10.14219/jada.archive.2006.0403.

CAMERON, N. M.; FISH, E. W.; MEANEY, M. J. Maternal influences on the sexual behavior and reproductive success of the female rat. Hormones and Behavior, v. 54, n. 1, p. effects may be prenatal bacterial infection exposure of the F1 generation. Periodontal disease is a type of infection caused primarily by Gram-negative anaerobic and microaerophilic bacteria that produce significant amounts of proinflammatory cytokines, mainly interleukin-1 $\beta$ and interleukin-6, prostaglandin E2, and tumor necrosis factor $\alpha$ (KUNNEN et al., 2014). Periodontal disease may influence the F1 generation through an indirect mechanism that involves proinflammatory mediators or direct bacterial assault on the amnion. Further studies are needed to verify the epigenetic/central/immune mechanisms that are involved in these transgenerational impairments.

The transmission of reproductive injury across generations may provide a mechanism by which other maternally mediated effects are transmitted, such as stress responsivity, cognitive ability, and reward responsivity. The transfer of information across generations through a nongenetic means has implications for clinical therapeutics, including many human disorders, and evolution (PEDERSEN et al., 2001).

In conclusion, we revealed that maternal periodontitis impaired reproductive performance of the adult $\mathrm{F} 1$ generation. These findings reinforce the importance of oral care during pregnancy because periodontitis may induce reproductive injury in adult offspring even if the offspring do not undergo any inflammatory/ infectious process during postnatal life or during gestation of the subsequent generation.

178-184, 2008. doi: 10.1016/j.yhbeh.2008.02.013.

COLLINS, J. G.; SMITH, M. A.; ARNOLD, R. R.; OFFENBACHER, S. Effects of Escherichia coli and Porphyromonas gingivalis lipopolysaccharide on pregnancy outcome in the golden hamster. Infection and Immunity, v. 62, n. 10, p. 4652-4655, 1994.

CURNO, O.; BEHNKE, J. M.; MCELliGOTT, A. G.; 
READER, T.; BARNARD, C. J. Mothers produce less aggressive sons with altered immunity when there is a threat of disease during pregnancy. Proceedings of the Royal Society B, v. 276, n. 1659, p. 1047-1054, 2009. doi: 10.1098/rspb.2008.1612.

GOLDENBERG, R. L.; HAUTH, J. C.; ANDREWS, W. W. Intrauterine infection and preterm delivery. The New England Journal of Medicine, v. 342, n. 20, p. 1500-1507, 2000. doi: 10.1056/NEJM200005183422007.

GYÖRFI, A.; FAZEKAS, Á.; SUBA, Z.; ENDER, F.; ROSIVALL, L. Neurogenic component in ligature-induced periodontitis in the rat. Journal of Clinical Periodontology, v. 21, n. 9, p. 601-605, 1994. doi: 10.1111/j.1600-051X.1994.tb00750.x.

HUGHES, F. J. Color atlas of dental medicine: periodontology - book review. British Dental Journal, v. 198, n. 10, p. 655, 2005. doi: 10.1038/sj.bdj.4812424.

KOCHENOUR, N. K. Adverse pregnancy outcome: sensitive periods, types of adverse outcomes, and relationships with critical exposure periods. Progress in Clinical and Biological Research, v. 160, p. 229-35, 1984.

KOTHIWALE, S. V.; DESAI, B. R.; KOTHIWALE, V. A.; GANDHID, M.; KONIN, S. Periodontal disease as a potential risk factor for low birth weight and reduced maternal haemomglobin levels. Oral Health \& Preventive Dentistry, v. 12, n. 1, p. 83-90, 2014. doi: 10.3290/j.ohpd.a31224.

KUHR, A.; POPA-WAGNER. A.; SCHMOLL, H.; SCHWAHN, C.; KOCHER, T. Observations on experimental marginal periodontitis in rats. Journal of Periodontal Research, v. 39, n. 2, p. 101-106, 2004. doi: 10.1111/j.1600-0765.2004.00710.x.

KUNNEN, A.; VAN PAMPUS, M.; AARNOUDSE, J. G.; VAN DER SCHANS, C.; ABBAS, F.; FAAS, M. M. The effect of Porphyromonas gingivalis lipopolysaccharide on pregnancy in the rat. Oral Diseases, v. 20, n. 6, p. 591-601, 2014. doi: 10.1111/odi.12177.

LIEFF, S.; BOGGESS, K. A.; MURTHA, A. P.; JARED, H.; MADIANOS, P. N.; MOSS, K.; BECK, J.; OFFENBACHER, $S$. The oral conditions and pregnancy study: periodontal status of a cohort of pregnant women. Journal of Periodontology, v. 75, n. 1, p. 116-126, 2004. doi: 10.1902/jop.2004.75.1.116.

LIN, D.; SMITH, M. A.; CHAMPAGNE, C.; ELTER, J.; BECK, J.; OFFENBACHER, S. Porphyromonas gingivalis infection during pregnancy increases maternal tumor necrosis factor alpha, suppresses maternal interleukin-10, and enhances fetal growth restriction and resorption in mice. Infection and Immunity, v. 71, n. 9, p. 5156-5162, 2003. doi: 10.1128/IAI.71.9.5156-5162.2003.

MANNEM, S.; CHAVA, V. K. The relationship between maternal periodontitis and preterm low birth weight: A case-control study. Contemporary Clinical Dentistry, v. 2, n. 2, p. 88-93, 2011. doi: 10.4103/0976-237X.83067.

MARCONDES, F. K.; BIANCHI, F. J.; TANNO, A. P. Determination of the estrous cycle phases of rats: some helpful considerations. Brazilian Journal Biology, v. 62, n. 4A, p. 609614, 2002. doi: 10.1590/S1519-69842002000400008.

MICHALOWICZ, B. S.; HODGES, J. S.; LUSSKY, R. C.; BADA, H.; RAWSON, T.; BUTTROSS, L. S.; CHIRIBOGA, C.; DIANGELIS, A. J.; NOVAK, M. J.; BUCHANAN, W.; MITCHELL, D. A.; PAPAPANOU, P. N. Maternal periodontitis treatment and child neurodevelopment at 24 to 28 months of age. Pediatrics, v. 127, n. 5, p. e1212-s1220, 2011. doi: 10.1542/peds.2010-3129.

MISRATH BANU, M. A.; RAMAMURTHY, J. Periodontitis a risk factor for pre-eclampsia in pregnant women. International Journal of Pharma and Bio Sciences, v. 5, n. 2, p. 736-739, 2014.

MOORE, S.; RANDHAWA, M.; IDE, M. A case-control study to investigate an association between adverse pregnancy outcome and periodontal disease. Journal of Clinical Periodontology, v. 32, n. 1, p. 1-5, 2005. doi: 10.1111/j.1600-051X.2004.00598.x.

NASSAR, C. A.; NASSAR, P. O.; INAGAKI, N. S.; GIRELLI JUNIOR, C. Efeito de antinflamatório no desenvolvimento de doença periodontal induzida: avalição radiográfica em ratos. Revista de Odontologia da UNESP, v. 32, n. 2, p. 125-130, 2003.

OFFENBACHER, S.; KATZ, V.; FERTIK, G.; COLLINS, J.; BOYD, D.; MAYNOR, G.; MCKAIG, R.; BECK, J. Periodontal infection as a possible risk factor for preterm low birth weight. Journal of Periodontology, v. 67, n. 10, p. 1103-1113, 1996. doi: 10.1902/jop.1996.67.10s.1103.

PAGE, R. C. The role of inflammatory mediators in the pathogenesis of periodontal disease. Journal of Periodontal Research, v. 26, n. 3, p. 230-242, 1991. doi: 10.1111/j.1600-0765.1991.tb01649.x.

PATTANASHETTI, J. I.; NAGATHAN, V. M.; RAO, S. M. 
Evaluation of periodontitis as a risk for preterm birth among preeclamptic and non-preeclamptic pregnant women - a case control study. Journal of Clinical and Diagnostic Research, v. 7, n. 8, p. 1776-1778, 2013. doi: 10.7860/JCDR/2013/6497.3308.

PEDERSEN, W. A.; MCCULlERS, D.; CULMSEE, C.; HAUGHEY, N. J.; HERMAN, J. P.; MATTSON, M. P. Corticotropin-releasing hormone protects neurons against insults relevant to the pathogenesis of Alzheimer's disease. Neurobiology of Disease, v. 8, n. 3, p. 492-503, 2001. doi: 10.1006/nbdi.2001.0395.

PENTEADO, S. H. W.; TEODOROV, E.; KIRSTEN, T. B.; ELUF, B. P.; REIS-SILVA, T. M.; ACENJO, M. K.; MELO, R. C.; SUFFREDINI, I. B.; BERNARDI, M. M. Prenatal lipopolysaccharide disrupts maternal behavior, reduces nest odor preference in pups, and induces anxiety: Studies of F1 and F2 generations. European Journal of Pharmacology, v. 738, p. 342-351, 2014. doi: 10.1016/j.ejphar.2014.05.058.

PIMENTEL, S. P.; CASATI, M. Z.; CIRANO, F. R.; RIBEIRO, F. V.; CASARIN, R. V.; KIRSTEN, T. B.; CHAVES-KIRSTEN, G. P.; DUARTE, P. M.; BERNARDI, M. M. Perinatal periodontal disease reduces social behavior in male offspring. Neuroimmunomodulation, v. 20, n. 1, p. 29-38, 2013. doi: 10.1159/000342987.

PISCOYA, M. D. B. V.; XIMENES, R. A. A.; SILVA, G. M.; JAMELLI, S. R.; COUTINHO, S. B. Maternal periodontitis as a risk factor for prematurity. Pediatrics International, v. 54, n. 1, p. 68-75, 2012. doi: 10.1111/j.1442-200X.2011.03502.x.

PITIPHAT, W.; JOSHIPURA, K. J.; GILLMAN, M. W.; WILLIAMS, P. L.; DOUGLASS, C. W.; RICH-EDWARDS,
J. W. Maternal periodontitis and adverse pregnancy outcomes. Community Dentistry and Oral Epidemiology, v. 36, n. 1, p. 3-11, 2008. doi: 10.1111/j.1600-0528.2006.00363.x.

SOMINSKY, L.; MEEHAN, C. L.; WALKER, A. K.; BOBROVSKAYA, L.; MCLAUGHLIN, E. A.; HODGSON, D. M. Neonatal immune challenge alters reproductive development in the female rat. Hormones and Behavior, v. $62, \quad$ n. $3, \quad$ p. 345-355, 2012. doi: 10.1016/j.yhbeh.2012.02.005.

TUCKER, R. Periodontitis and pregnancy. The Journal of the Royal Society for the Promotion of Health , v. 126, n. 1, p. 24-27, 2006. doi: 10.1177/1466424006061170.

WALKER, A. K.; HILES, S. A.; SOMINSKY, L.; MClAUGHLIN, E. A.; HODGSON, D. M. Neonatal lipopolysaccharide exposure impairs sexual development and reproductive success in the Wistar rat. Brain, Behavior, and Immunity, v. 25, n. 4, p. 674-684, 2011. doi: 10.1016/j.bbi.2011.01.004.

WANG, Y. L.; LIOU, J. D.; PAN, W. L. Association between maternal periodontal disease and preterm delivery and low birth weight. Taiwanese Journal of Obstetrics \& Gynecology, v. 52, n. 1, p. 71-76, 2013. doi: 10.1016/j.tjog.2013.01.011.

XIAO, Y.; KONG, X. B.; CHEN, J. Y.; RUAN, Y. Relationship between recurrent spontaneous abortion and the level of interferon- $\gamma$ and interleukin- 4 in peripheral blood and gingival crevicular fluid of patients with chronic periodontitis. Chinese Journal of Stomatology, v. 48, n. 3, p. $150-154,2013$. 